\title{
NATIONAL AND INTERNATIONAL SPILLOVERS FROM R\&D: Comparing a Neoclassical and an Endogenous Growth Approach
}

\author{
By \\ Henrik Braconier \\ Department of Economics \\ Lund University \\ P.O. Box 7082 \\ S-220 07 Lund, Sweden \\ Fredrik Sjöholm \\ Stockholm School of Economics \\ P.O. Box 6501 \\ S-113 83 Stockholm, Sweden
}

Working Paper Series in Economics and Finance No 211

December 1997

\begin{abstract}
:
Two models where productivity growth is caused by spillovers from $R \& D$ are analysed using a sample of nine manufacturing industries in six large OECD-countries between 1979 and 1991. The first model is based on traditional productivity analysis where growth in $\mathrm{R} \& \mathrm{D}$ stocks causes productivity growth. The second model is based on the endogenous growth literature where the level of R\&D expenditures is assumed to increase productivity growth. The empirical results indicate stronger support for the latter model. The pattern of spillovers is also investigated. The results suggest that spillovers from R\&D exist within industries, both nationally and internationally. There is, however, little evidence of spillovers between industries. The empirical evidence further suggests that intra-industry spillovers are confined to industries that are relatively R\&Dintensive. Finally, direct foreign investment seem to facilitate the diffusion of R\&D results, but we do not find any effect on growth from R\&D embodied in intermediate products.
\end{abstract}

Key words: R\&D; Spillovers; Growth; Trade; DFI

JEL classification: O32; O40 


\section{Introduction*}

Economists have for some time stressed the importance of Research and Development $(\mathrm{R} \& \mathrm{D})$ as a source of economic growth. ${ }^{1}$ It has been argued that the results of R\&D are only partially excludable and also non-rival. Consequently, the internal effect of $R \& D$ on the inventing firm's productivity may be accompanied by an external effect called the spillover effect, on other firms' productivity. In recent years it has been argued that spillovers from $R \& D$ may be one possible engine of endogenous growth. ${ }^{2}$ The assumption behind R\&D based endogenous growth models is that accumulation of $\mathrm{R} \& \mathrm{D}$ does not face diminishing returns.

One important aspect of spillovers in connection with economic growth is the relative extent of national and international spillovers. If, on one hand, spillovers are limited to the country where $\mathrm{R} \& \mathrm{D}$ is conducted, the growth rate in each country will be determined by the country's own R\&D-efforts. If, on the other hand, spillovers take place across borders, then the growth rates in real income will tend to converge across countries. Empirical studies in general confirm the existence of spillovers both between firms in the same industry and between firms in different industries. ${ }^{3}$ Furthermore, Bernstein and Mohnen (1994), Coe and Helpman (1995) and Nadiri and Kim (1996) present empirical evidence on international spillovers from R\&D.

This study analyse different aspects on spillovers from R\&D. Firstly, we study whether productivity growth is affected by growth in $\mathrm{R} \& \mathrm{D}$ stocks or levels of $\mathrm{R} \& \mathrm{D}$-expenditures. Within the neoclassical framework we would expect growth in R\&D stocks to positively affect growth in productivity. ${ }^{4}$ Growth in productivity is - in some of the most important theoretical work on endogenous growth - determined by the level of resources devoted to R\&D. ${ }^{5}$ The

\footnotetext{
* Remark: We thank Magnus Blomström, Rikard Forslid, Steven Globerman, Ari Kokko and Bo Södersten for valuable comments. Financial support from the Bank of Sweden Tercentenary Foundation and from the Swedish Council for Research in the Humanities and Social Sciences are gratefully acknowledged.

${ }^{1}$ See e.g. Shell (1966).

${ }^{2}$ See e.g. Romer (1990) and Grossman and Helpman (1991).

${ }^{3}$ For an overview see e.g. Griliches (1994).

${ }^{4}$ See e.g. Grilliches (1979).

${ }^{5}$ See e.g. Romer (1990) and Grossman and Helpman (1991).
} 
endogenous growth approach has not received much empirical attention. ${ }^{6}$ The results may thus indicate whether spillovers from R\&D primarily lend support to endogenous or neoclassical growth models. Secondly, we will examine domestic- as well as international spillovers at an industry level. Finally, we try to identify possible channels for R\&D spillovers. Two potential channels for R\&D spillovers are examined: the localisation of direct foreign investment (DFI) and the purchase of intermediate products. In examining these issues, pooled time-series and cross-section data for six large OECD countries will be used. The sample includes nine manufacturing industries and covers the period 1979 to 1991.

Our results indicate that productivity growth is affected by levels of $R \& D$ expenditures rather than by the growth rate of $R \& D$ stocks. The results are, thus, in line with the endogenous growth literature. In the endogenous growth approach we find industry-specific spillovers from R\&D but no spillovers between industries. ${ }^{7}$ Intra-industry spillovers seem to take place both within and between countries. Moreover, intra-industry spillovers are found only in relatively research-intensive industries. Finally, our results show that R\&D transferred through DFI increases productivity growth. We do not find any effect on productivity growth from $\mathrm{R} \& \mathrm{D}$ embodied in domestic- or foreign intermediate products.

The rest of the study is organised as follows. In part II we discuss the background to the study. In part III we present our models for spillovers and productivity and in part IV we discuss the included variables. The results from the econometric estimations are shown and discussed in part V. Conclusions are presented in part VI.

\section{Background}

$R \& D$ is likely to increase the productivity in the firm that conducts $R \& D$, as new products and processes will enable the firm to increase profits or to decrease costs. The direct effect may be accompanied by a spillover effect on other firms' productivity. The spillover

\footnotetext{
${ }^{6}$ Two exceptions are Jones (1995a) and Jones (1995b) who examine R\&D-based endogenous growth models with time-series data for individual countries.

${ }^{7}$ We use, for convienence, the term spillovers for all R\&D effects although a sector's productivity gains from its' own R\&D is, strictly speaking, a combination of spillovers (externalities) and direct effects.

${ }^{8}$ See e.g. Terleckyj (1980), Sterlacchini (1989).
} 
effects may take place through several channels. Firstly, imperfect intellectual property rights combined with the low marginal cost of reproducing results from $R \& D$ imply that technologies developed in one firm may spread to other firms through imitation, reverse engineering or recruitment of the inventing firm's R\&D personnel. Furthermore, license agreements may facilitate the spread of technologies developed through R\&D.

New R\&D results may also be embodied in input goods. If the firm which produces the input good is unable to appropriate all the productivity effects from its $R \& D$, firms buying the improved input goods will enjoy increased productivity through the embodied R\&D. Previous studies which relate inter-industry spillovers through input-output matrices find substantial inter-industry spillovers at a domestic level. ${ }^{8}$ Sakurai et al (1997) however, found no effect on productivity growth in the manufacturing sector from domestic and imported input goods, but they found an effect in the service industries. The positive effect on productivity growth was found for both domestic and imported products but was not present in all the studied countries.

MNCs conduct a large share of the world's total R\&D and they possess the bulk of the world's stock of advanced commercial technologies. MNCs may therefore be an important channel for international R\&D diffusion. DFI may increase a country's productivity through several different channels. Firstly, DFI may have a direct effect on an industry's aggregated productivity if foreign MNCs exhibit higher levels of productivity than domestic firms. Moreover, the localisation of foreign firms may increase the flow of new R\&D results. Although there seems to be a tendency for "outlocalisation" of R\&D in MNCs, most of the $R \& D$ is still conducted within the parent company and the results are passed on to the affiliates abroad. ${ }^{9}$ Mansfield and Romeo (1980) find technologies transferred to affiliates to be of a later vintage than technologies sold to outsiders through licensing agreements and joint ventures. Behrman and Wallender (1976), Davidson and McFetridge (1985) and McFetridge (1987) do also suggest intra-firm transfer of new technologies to be relatively important in comparison to inter-firm transfer of technologies. The productivity gains from new technologies are therefore likely to be larger for the affiliates than for other firms. Fors (1997) found that R\&D results transferred from the parent firm to the affiliates increased the affiliates' productivity. Hosting

\footnotetext{
${ }^{9}$ For a discussion see Globerman (1997).
} 
affiliates of foreign MNCs should therefore be an important channel for the inflow of new foreign $R \& D$ results into the country. Furthermore, the knowledge transferred to the affiliates often leaks out to local firms, both within the industry and between industries. This spillover from the foreign- to the local firms will increase the latter group's productivity. There are several possible channels for spillovers from foreign affiliates to domestic firms. Knowledge, for instance, may be transferred through labour turnover, support of linkage industries or demonstration effects. ${ }^{10}$

Contrary to the results from the micro-based studies mentioned above, Lichtenberg and van Pottelsberghe de la Potterie (1996) find no evidence that inward DFI work as a channel for R\&D spillovers in an aggregate cross-country study.

\section{Spillovers from R\&D}

Two different approaches to the analysis of $\mathrm{R} \& \mathrm{D}$ and productivity growth are investigated. The first and most common method is based on the neoclassical assumption that accumulation of reproducible factors of production face diminishing returns. Consequently, stocks of reproducible factors, such as $\mathrm{R} \& \mathrm{D}$, will converge to a steady state level and growth will cease. We call this specification the traditional approach, as the empirical specification is based on the traditional perpetual inventory method. The second specification builds on theoretical work on endogenous growth, where the accumulation of $R \& D$ does not face diminishing returns. Stocks of R\&D may therefore grow indefinitely. The second specification will be termed the endogenous growth approach.

To show how R\&D may affect productivity growth, we assume a Cobb-Douglas production function for final production:

$Y_{i}=A_{i} K_{i}^{s_{K}^{i}} L_{i}^{s_{L}^{i}}$

\footnotetext{
${ }^{10}$ See e.g. Blomström and Kokko (1997).
} 
$Y_{i}$ is net production (value-added), $A_{i}$ is the productivity (technology) level, $K_{i}$ and $L_{i}$ are physical capital and labour force, respectively. $s_{K}^{i}$ and $s_{L}^{i}$ are the output elasticities with respect to capital and labour. The current level of productivity in industry $i\left(A_{i}\right)$ is assumed to be dependent on the stock of R\&D in the industry $\left(R_{i}\right)$, the stock of R\&D in other industries $\left(R_{j}\right)$ and of other factors $\left(Z_{i}\right)$, which will be discussed later.

$A_{i}=Z_{i} R_{i}^{\gamma_{i}} \prod_{j=1, j \neq i}^{n} R_{j}^{\gamma_{j}}$

where $\gamma_{i}$ measures intra-industry spillovers from $\mathrm{R} \& \mathrm{D}$ while $\gamma_{j}$ is the spillover effect from $\mathrm{R} \& \mathrm{D}$ in industry $j$ to productivity in industry $i{ }^{11}$ If $\gamma_{j}$ is equal to zero, there are no spillovers from industry $j$ to industry $i$. If $\gamma_{j}$ is equal to $\gamma_{i}$ then productivity in industry $i$ is affected by a unit of R\&D in industry $j$ as much as by a unit of R\&D in industry $i$.

In the present study, we analyse spillovers within and between industries and within and between countries. Initially, we assume that $R \& D$ in all industries in the rest of the economy affects productivity in industry $i$ to an equal extent. Furthermore, we assume that there are no differences in the spillover effects from different countries. We therefore respecify equation (2) as

$$
A_{i}=Z_{i} R_{s}^{\gamma_{s}} R_{d}^{\gamma_{d}} R_{s^{*}}^{\gamma_{s^{*}}} R_{d^{*}}^{\gamma_{d^{*}}},
$$

where,

$R_{s}$ - domestic industry $R \& D-\mathrm{R} \& \mathrm{D}$ stock in the own industry.

$R_{d}$ - total domestic $R \& D$ - R\&D stock in the other industries in the own country.

$R_{s^{*}}$ - foreign industry $R \& D$ - $\mathrm{R} \& \mathrm{D}$ stock in the same industry in the other countries.

$R_{d^{*}}$ - total foreign $R \& D$ - R\&D stock in the other industries in the other countries.

By taking logs and differentiating equation (2') we can define the growth rate in productivity as

\footnotetext{
${ }^{11}$ Note, again, that in the case of the industry's own R\&D efforts, we cannot distinguish between inter-firm spillovers and excess returns to the firm that conducts R\&D.
} 


$$
\hat{a}=l\left(Z_{t}, Z_{t-1}\right)+\gamma_{s} \hat{r}_{s}+\gamma_{d} \hat{r}_{d}+\gamma_{s^{*}} \hat{r}_{s^{*}}+\gamma_{d^{*}} \hat{r}_{d^{*}}
$$

where lower case letters with 'hats' indicate growth rates. Equation (3) states that productivity growth is determined by the growth rates of the four respective R\&D stocks.

To see how the traditional model differs from the endogenous growth approach, we state output of R\&D results in industry $i$ as

$$
\dot{R}_{i}=\lambda E_{i} R_{i}^{\sigma}-\delta R_{i}
$$

$R_{i}$ is the stock of R\&D and $\dot{R}_{i}$ denotes the change in the stock of $\mathrm{R} \& \mathrm{D}, \lambda$ is an efficiency parameter, $E_{i}$ denotes real resources engaged in $\mathrm{R} \& \mathrm{D}$ and $\delta$ is the rate of depreciation. In equation (4), $\sigma$ is the critical parameter that determines whether the stock of R\&D - and consequently final output - will grow indefinitely or converge to a steady state level.

In the neoclassical analysis of $R \& D$ and productivity, accumulation of $R \& D$ faces diminishing returns and hence the stock of $R \& D$ will converge to a steady state level. In order to ensure the stock of $R \& D$ in equation (4) converges to a steady state level, we have to assume $\sigma$ to be less than one. A common assumption in traditional productivity analysis is to set $\sigma$ to zero and $\lambda$ to one. ${ }^{12}$ This enables us to simplify equation (4) to

$$
\dot{R}_{i}=E_{i}-\delta R_{i}
$$

which is the standard perpetual inventory equation. By computing the growth rate of the R\&Dstock from (4') and inserting it into (3) we get the perpetual inventory version of the neoclassical model of how R\&D may affect productivity growth.

If we want the model presented in (4) to incorporate R\&D-driven long-run growth, $\sigma$ must be equal to or larger than one. In the linear case, $\sigma$ is equal to one and (4) simplifies to,

\footnotetext{
${ }^{12}$ See e.g. Grilliches (1979).
} 


$$
\dot{R}_{i}=\lambda E_{i} R_{i}-\delta R_{i}
$$

which is the standard approach in most theoretical analyses of endogenous growth. ${ }^{13}$ As we see from (4"), the production of new R\&D in the endogenous growth approach is linear in the level of $\mathrm{R} \& \mathrm{D}$. As long as $\lambda E_{i}$ is larger than $\delta$, long-run growth in the stock of $\mathrm{R} \& \mathrm{D}$ will take place. We can combine (3) and (4") to

$$
\hat{a}=\alpha_{0}+l\left(Z_{t}, Z_{t-1}\right)+\alpha_{s} E_{s}+\alpha_{d} E_{d}+\alpha_{s^{*}} E_{s^{*}}+\alpha_{d^{*}} E_{d^{*}},
$$

where $\alpha_{0}$ incorporates the effects from the rate of depreciation $(\delta)$ in (4"). Equation (5) captures the central theme of endogenous growth models with R\&D-driven growth, such as e.g. Romer (1990) and Grossman and Helpman (1991), where productivity growth is determined by the amount of real resources engaged in R\&D. Equation (5) differs from Romer's formulation in two respects. Domestic spillovers in our formulation are not necessarily complete and international spillovers may take place. When we examine whether DFI or purchase of intermediate products facilitates R\&D spillovers, we will modify equation 5 so that the weights of different R\&D stocks will be a function of DFI and input goods.

If we compare the two approaches as they are formulated in (4') and (4"), the crucial question is how does current R\&D affect the output of future R\&D? Although traditional growth accounting does not explicitly describe production in the R\&D sector, the formulation in (4') implies that the productivity of resources diverted to R\&D does not increase as the level of the $R \& D$ stock changes in society. $R \& D$ produces new pieces of technology that are applied in final-good production, but current $R \& D$ does not affect the productivity of future $R \& D$. In the traditional model, a given amount of $R \& D$ expenditure produces a given amount of new R\&D.

In the endogenous growth approach, as formulated by Romer, production of new R\&D is instead positively correlated with previous $R \& D$ :

\footnotetext{
${ }^{13}$ See e.g. Romer (1990).
} 
"...a college-educated engineer working today and one working 100 years ago have the same human capital,... The engineer working today is more productive because he or she can take advantage of all the additional knowledge accumulated as design problems were solved during the last 100 years."

(Romer (1990) pp. 83-84)

The improvements in technology that society at large has experienced will increase the productivity of researchers. $R \& D$ therefore has two effects. The first, intentional effect is to increase productivity in final production through development of new products and processes. The second, unintended effect is to increase productivity of future $R \& D$ by increasing the stock of $R \& D$ results available for all firms in the economy.

\section{Data and Measures}

We investigate the relationship between $R \& D$ and productivity in the manufacturing industry in six large OECD-countries; France, Germany, Italy, Japan, the United Kingdom and the United States. The data is disaggregated into nine different manufacturing industries for each country. ${ }^{14}$

Total factor productivity will be used to measure productivity. We can use equation (1) to solve for growth in TFP

$$
\hat{a}=\hat{y}-s_{K} \hat{k}-s_{L} \hat{l}
$$

where $\hat{y}, \hat{k}$ and $\hat{l}$ denotes growth in value-added, capital stock and employment respectively. We assume that the respective output elasticities are equal to $s_{K}$ and $s_{L}$, the capital- and labour compensation shares of value-added. Consequently we implicitly assume constant-returns-toscale in final production, as $s_{K}+s_{L}=1$. This method is common in productivity analysis and measures productivity correctly under a number of assumptions. ${ }^{15}$ In the short-run, wage rigidity combined with fluctuations in value-added will result in highly volatile shares of value-

\footnotetext{
${ }^{14}$ The sample includes a total of 49 sectors, as we lack data for some sectors in some of the countries. All data presented in the paper are in 100 billion U.S. \$ (PPP) and valued at 1985 prices. The study covers the period 1979-1991. See Appendix for further details.

${ }^{15}$ The assumptions are, in addition to constant returns to scale: disembodied technical progress, continuous technical change and competitive markets (see Hulten (1978)).
} 
added for capital and labour. We therefore use the average share of value-added for labour and capital over the whole period, which should be less sensitive to business cycles. ${ }^{16}$ International discrepancies in industry-wise factor shares are - due to different measurement methods - likely to capture measurement differences rather than technology differences. ${ }^{17} \mathrm{We}$ therefore use international average values of factor shares for each industry to compute growth in TFP. Observations on value-added, wages, employment and capital stocks are from OECD (1993).

In the theoretical analysis in part II, TFP growth is determined by real resources devoted to R\&D. Due to empirical considerations, we use real $R \& D$ expenditures rather than physical units in the empirical analysis. Data availability and quality makes R\&D expenditures preferable to e.g. the number of scientists. The data is taken from OECD (1992) and covers private sector $\mathrm{R} \& \mathrm{D}$ expenditures.

In the traditional model, we construct the stock of $R \& D$ by adding together inputs into the $R \& D$ process, i.e. real expenditures on $R \& D$, and assuming a five percent depreciation rate for R\&D. ${ }^{18}$ This method is similar to that used by Englander et al (1988) and Coe and Helpman (1995). In the traditional model, growth in R\&D stocks is used as the independent variables in the econometric analysis, as shown in equation (3). In the endogenous growth specification, real $R \& D$ expenditures are used as the independent variables, as shown in equation (5).

Initially, as we discussed in part II, we assume that the effects of R\&D on productivity are symmetric across countries and industries. Later, when we investigate different channels of R\&D spillovers, we will use input-output tables to compute the amount of $R \& D$ available to different industries through the purchase of domestic and imported intermediate products. All input-output tables are from OECD (1995). ${ }^{19}$ Capital goods may embody R\&D to a larger extent than other types of goods. Input-output matrices on capital formation, unfortunately,

\footnotetext{
${ }^{16}$ We also tried to estimate change in productivity with two-year average factor shares, but this measure produced similar results as the constant shares measure did.

${ }^{17}$ See Meyer-zu-Schlochtern (1988).

${ }^{18}$ Observations on R\&D expenditures between 1963-1991 have been used.

${ }^{19}$ Matrices were available for the following years: France: 1980, 1985, 1990. Germany: 1978, 1986, and 1990. Italy: 1985. Japan: 1980, 1985, and 1990. U.K: 1979, 1984, and 1990. U.S: 1982, 1985, and 1990.
} 
suffer from a variety of problems. ${ }^{20}$ We are therefore limited to using matrices on purchase of intermediate products. Our analysis of the effects of DFI focuses on intra-industry spillovers. The data on DFI-stocks is from United Nations (1993) for a single year for each country. ${ }^{21}$

In the short-run, business cycles will affect TFP. We would expect productivity to increase during economic booms because of a higher utilisation of the capital stock and the labour force, while we expect productivity to decrease during economic recessions. We control for business cycle effects on productivity growth by including the variable Business cycle for which we anticipate a positive coefficient.

The construction of the variables, descriptive statistics and the availability of data is shown in the Appendix.

\section{Econometric Estimations and Results}

\section{Method}

As the analysis in part II showed, growth in TFP is a function either of the growth of the $R \& D$ stock or of the level of $R \& D$ expenditures. Both approaches will be tested econometrically. The test equation is

$$
\hat{\mathrm{tfp}}=\beta_{0}+\mathbf{Z} \lambda+\mathbf{X} \gamma+\mathbf{e}
$$

In equation (7) $\beta_{0}$ is a constant. $\mathbf{Z}$ denotes country, time and sector-specific dummy variables and the control variable business cycle. $\mathbf{X}$ is the matrix of observations on the R\&D variables and $\mathbf{e}$ is the residual. Equation (7) will be estimated by ordinary least squares.

An empirical problem is the construction of lag structures, as expenses on $R \& D$ is likely to produce results with a certain time lag and the application of the results to production

\footnotetext{
${ }^{20}$ For instance, comparability problems between countries, lack of appropriate price deflators, separation problems between domestically produced and imported capital goods, etc. See OECD (1995 pp. 14-16).

${ }_{21}$ The respective years are: 1987 for the U.K, 1989 for France, 1990 for Italy, Germany, Japan and the U.S.
} 
will involve further delay. ${ }^{22}$ In view of previous studies and the length of our time series, a lag length of five years was chosen. The data reveals that different lags are highly serially correlated, which is a common phenomenon when one is working with time-series of R\&D. To overcome this problem, we use the unweighted averages of lags 1 to 5. Generally, pooling of observations is likely to result in heteroscedasticity, as one would not expect the variance to be equal across industries. Pre-testing did reveal some signs of heteroscedasticity, so we estimate the variance-covariance matrix using the method proposed by White (1980).

\section{Results}

In examining the effect of $R \& D$ on productivity growth we start with the traditional model and continue with the endogenous growth approach. Initially we examine intra-industry spillovers from R\&D both nationally and internationally. We continue by examining whether, in addition to the intra-industry spillover, there are inter-industry spillovers at either a national or an international level. We also split the sample into more R\&D-intensive and less R\&Dintensive industries. Finally, we examine if DFI and purchase of domestic and imported intermediate products facilitate R\&D spillovers. The stability of all regressions is examined by introducing country and sector-specific dummy variables. The results with country and sector specific dummy variables are discussed and available from the authors on request. Moreover, as an alternative to our business cycle variable we used time dummy variables, which did not have any effect on the qualitative results.

Table 1 - Intra-industry spillovers in the traditional model

\begin{tabular}{l|l|l|}
\hline Variables & Regression 1 & Regression 2 \\
\hline & \\
& \\
& Branch (1974) finds that the effect of R\&D on productivity peaked after two years. Grilliches (1979) \\
recommends - on the basis of case-study evidence- a lag-structure that peaks at 3 to 5 years and then declines \\
rapidly. Grilliches discusses the problem of functional forms of the lag structure and recommends assuming a \\
particular form a priori as we should "...not expect the data to answer such fine questions."
\end{tabular}




\begin{tabular}{|l|l|l|}
\hline Constant & 0.008 & 0.004 \\
Business cycle & $(1.05)$ & $(0.46)$ \\
& 0.673 & 0.680 \\
Growth in industry $R \& D$ stock & $(7.63) * * *$ & $(7.81)^{* * *}$ \\
Growth in domestic industry $R \& D$ stock & -0.160 & -- \\
Growth in foreign industry $R \& D$ stock & $(1.22)$ & - \\
Number of observations & - & $(1.26)$ \\
$\overline{\mathrm{R}^{2}}$ & 621 & -0.021 \\
\hline
\end{tabular}

Note: $* * *$ Coefficient significantly different from zero at the $1 \%$ level. -- Not estimated. Figures in parenthesis are t-statistics for coefficients, based on White's (1980) estimate of the covariance matrix.

\section{The Traditional Model}

In Table 1 we show the results for intra-industry spillovers from the traditional approach. The first regression examines the effect on productivity growth from the Growth in industry $R \& D$ stock, which consist of the domestic- as well as the foreign $R \& D$ stock within the industry in question. In the second regression, we have split the variable Growth in industry $R \& D$ stock into a domestic- and a foreign component. The estimations do not provide any support for intra-industry spillovers from $\mathrm{R} \& \mathrm{D}$, as the coefficient is negative and statistically insignificant. The coefficient for the control variable, Business cycle, is highly significant with the anticipated positive sign in all estimations. The inclusions of the different sets of dummy variables do not change the overall results. The fit of the regression is quite low, although the $\bar{R}^{2}: s$ are within the normal range for industry-based productivity studies. ${ }^{23}$

Table 2 - Inter-industry spillovers in the traditional model \begin{tabular}{|l|l|l|}
\hline Variables & Regression 3 & Regression 4 \\
\hline
\end{tabular}

\footnotetext{
${ }^{23}$ See e.g. Sveikauskas (1981), Scherer (1982) and Sterlacchini (1989).
} 


\begin{tabular}{|l|l|l|}
\hline Constant & 0.024 & -0.006 \\
Business cycle & $(1.83)^{*}$ & $(0.27)$ \\
& 0.709 & 0.676 \\
Growth in industry $R \& D$ stock & $(8.05)^{* * *}$ & $(7.66)^{* * *}$ \\
Growth in domestic other industry $R \& D$ & -0.138 & -0.175 \\
stocks & $(1.07)$ & $(1.32)$ \\
Growth in foreign other industryR\&D & $(1.52)$ & -- \\
stocks & -- & 0.237 \\
Number of observations & & $(0.70)$ \\
$\overline{\mathrm{R}^{2}}$ & 621 & 621 \\
\hline
\end{tabular}

Note: * Coefficient significantly different from zero at the $10 \%$ level. $* * *$ Coefficient significantly different from zero at the $1 \%$ level. -- Not estimated. Figures in parenthesis are t-statistics for coefficients, based on White's (1980) estimate of the covariance matrix.

In regressions 3 and 4 - presented in Table 2 - we add the variables Growth in domestic other industry R\&D stock and Growth in foreign other industry R\&D stock in order to examine whether there are any inter-industry spillovers from R\&D in the traditional model. Regression 3 includes the effect of total domestic R\&D conducted in other industries in the country and regression 4 includes the effect of total foreign R\&D in other industries. Neither domestic $R \& D$ in other industries, nor foreign $R \& D$ in other industries have a positive and significant coefficient. This suggests that there are no inter-industry spillovers from R\&D in the traditional model. ${ }^{24}$ As in the previous estimations, the coefficient for the industry's own R\&D is not statistically significant and the results are not changed by the inclusion of dummy variables. The coefficient for Business cycle is positive and statistically significant in both estimations.

\section{The Endogenous growth approach}

\footnotetext{
${ }^{24}$ Perfect multicollinearity in the endogenous growth approach prevents us from including all four R\&D measures in the same regression. As we want to be able to compare the results from the two models, we only present the above estimations for the traditional model, but estimations with all four R\&D measures did not change the general results.
} 
The results from the estimations based on the endogenous growth approach are presented in Tables 3 and 4 . We show the results for intra-industry spillovers from R\&D in Table 3. These results differ from those using the traditional model. The industry's own R\&D has a positive and statistically significant effect on productivity growth. When we split industry-specific R\&D into domestic and foreign components, the results lend support to foreign spillovers rather than to domestic ones. The two variables are, however, relatively highly correlated - with a correlation coefficient of 0.41 - which may affect the effectiveness of the estimation. Estimations using only the domestic industry R\&D yield a positive and significant coefficient for this variable. Furthermore, we cannot statistically reject the hypothesis that the coefficients for domestic and foreign R\&D are equal. ${ }^{25}$ Finally, one should be aware that the coefficient for domestic industry R\&D should be interpreted as an excess or social return to $R \& D$ and not a total return. ${ }^{26}$ Inclusions of different sets of dummy variables do not affect the results in regression 5 significantly. Including sector-specific dummies in regression 6 makes the coefficient for domestic industry $R \& D$ expenditures positive and statistically significant.

Table 3 - Intra-industry spillovers in the endogenous growth approach

\begin{tabular}{|l|l|l|}
\hline Variables & Regression 5 & Regression 6 \\
\hline Constant & -0.003 & -0.003 \\
Business cycle & $(1.12)$ & $(1.12)$ \\
& 0.672 & 0.672 \\
Industry R\&D expenditures & $(7.65)^{* * *}$ & $(7.65)^{* * *}$ \\
Domestic industry R\&D expenditures & 0.017 & -- \\
Foreign industry R\&D expenditures & $(4.02)^{* * *}$ & 0.010 \\
Number of observations & -- & $(0.61)$ \\
& 621 & 0.018 \\
$\mathrm{R}^{2}$ & & $(3.57)^{* * *}$ \\
\hline
\end{tabular}

Note: $* * *$ Coefficient significantly different from zero at the $1 \%$ level. -- Not estimated. Figures in parenthesis are t-statistics for coefficients, based on White's (1980) estimate of the covariance matrix.

Table 4 presents the results from regressions examining whether there are any interindustry spillovers - in addition to the intra-industry spillovers - in the endogenous growth

\footnotetext{
${ }^{25}$ The test of the null hypothesis that the coefficients are equal yields an f-statistic of 0.07 with 4 and 617 degrees of freedom, which is not significant at the $10 \%$ level. Consequently, we cannot reject equality.

${ }^{26}$ See Schankerman (1981) for a thorough discussion on why the coefficient for own technological knowledge should be interpreted as a spillover effect or an excess return to R\&D and not a total return.
} 
approach. Regression 7 includes domestic $R \& D$ and regression 8 includes foreign $R \& D$, conducted in other industries. The results do not show any signs of inter-industry spillovers from R\&D. Neither of the two coefficients for other industries' R\&D is positive and significant. This result does not change when we include different sets of dummy variables. As in the previous estimations of the endogenous growth approach, the industry's own R\&D has a positive effect on productivity growth.

Table 4 - Inter-industry spillovers in the endogenous growth approach

\begin{tabular}{|l|l|l|}
\hline Variables & Regression 7 & Regression 8 \\
\hline Constant & 0.000 & -0.004 \\
Business cycle & $(0.02)$ & $(0.45)$ \\
Industry $R \& D$ expenditures & 0.674 & 0.67 \\
& $(7.67)^{* * *}$ & $(7.51)^{* * *}$ \\
Domestic other industry $R \& D$ & 0.014 & 0.017 \\
expenditures & $(3.35)^{* * *}$ & $(2.32)^{* *}$ \\
Foreign other industry $R \& D$ & -0.014 & -- \\
expenditures & $(1.60)$ & \\
Number of observations & -- & 0.000 \\
$\overline{\mathrm{R}^{2}}$ & & $(0.07)$ \\
\hline
\end{tabular}

Note: $* *$ Coefficient significantly different from zero at the $5 \%$ level. $* * *$ Coefficient significantly different from zero at the $1 \%$ level. -- Not estimated. Figures in parenthesis are t-statistics for coefficients, based on White's (1980) estimate of the covariance matrix.

\section{R\&D Effects in Different Types of Industries}

In previous estimations we have assumed $R \& D$ to affect productivity growth similarly across all industries. It is possible that the effect differs, for instance, between R\&D intensive industries and others. Consequently, we divide the nine industries into two groups. Industries where the unweighted average R\&D expenditures are higher than $1 \%$ of value-added have been included in the group $R \& D$ intensive industries and industries where $R \& D$ expenditures are less than $1 \%$ of value added have been included in the group Other industries. ${ }^{27}$

\footnotetext{
${ }^{27}$ The group $R \& D$ intensive industries consists of Chemical products (350), Non-metallic mineral products (360), Basic metal industries (370), Fabricated metal products (380) and Other manufacturing (390). The group
} 
The traditional model did not reveal positive effects on productivity growth from R\&D in any of the two samples. Table 5 presents the results from the endogenous growth approach. Industry-specific $R \& D$ has a positive and significant effect on productivity growth in $R \& D$ intensive industries. However, whereas inclusion of country-specific dummies and time dummies do not change the results, sector-specific dummies make the coefficient for industry $\mathrm{R} \& \mathrm{D}$ expenditures statistically insignificant. There is no positive effect on productivity growth from own $R \& D$ in industries that are not $R \& D$ intensive. In fact, the coefficient for own $R \& D$ has in this latter sample a non-intuitive negative coefficient. Hence, the positive growth effect from industry-specific $R \& D$ is confined to the $R \& D$ intensive industries.

Table 5 - Results from more and less $R \& D$ intensive sectors within the endogenous growth approach

\begin{tabular}{|l|l|l|}
\hline & R\&D intensive industries & Other industries \\
\hline Variables & Regression 9 & Regression 10 \\
\hline Constant & -0.004 & 0.008 \\
Business cycle & $(0.95)$ & $(1.78)^{*}$ \\
Industry R\&D expenditures & 0.900 & 0.350 \\
Number of observations & $(7.02)^{* * * *}$ & $(3.80)^{* * *}$ \\
$\overline{\mathrm{R}^{2}}$ & 0.012 & -0.708 \\
& $(2.28)^{* * *}$ & $(2.16)^{* *}$ \\
& 353 & 268 \\
\hline
\end{tabular}

Note: * Coefficient significantly different from zero at the $10 \%$ level. $* *$ Coefficient significantly different from zero at the $5 \%$ level. *** Coefficient significantly different from zero at the $1 \%$ level. Figures in parenthesis are t-statistics for coefficients, based on White's (1980) estimate of the covariance matrix.

$\mathrm{R} \& \mathrm{D}$ conducted in other industries, domestic as well as foreign, was not found to have a positive effect on productivity growth in any of our two samples. Splitting Industry $R \& D$ expenditures into a domestic and a foreign component does not alter the picture. In R\&D intensive industries the results indicate that the foreign component has a positive and significant effect on TFP growth while the effect of the domestic component is positive but insignificant. In non $R \& D$ intensive industries, the domestic component is negative and significant at the $10 \%$ level while the foreign component is negative but insignificant. The

Other industries includes Food, beverages and tobacco (310), Textiles (320), Wood (330) and Paper products (340). 
difference between domestic and foreign coefficients is not statistically significant for any of the two samples.

\section{The Effect of DFI and Intermediate Products}

The results on growth from $R \& D$ embodied in domestic and imported input goods and from R\&D transferred through DFI are shown in Table 6. The construction of DOMEMB, IMPEMB and DFIRD are shown in table A2 in the appendix. The use of DFI and intermediate products did not give statistically significant effects in the traditional approach and is therefore not shown. In the endogenous growth approach, Business cycle and Domestic industry $R \& D$ expenditures are statistically significant with the expected sign in all estimations. ${ }^{28}$ If industries benefit from $R \& D$ embodied in products from other domestic industries, we would expect a positive coefficient for DOMEMB. Instead, the coefficient is negative in regression 11 and regression 14 . None of the coefficients, however, are statistically significant. There does not seem to be productivity gains from R\&D embodied in domestically produced intermediate products.

The possibility that industries benefit from R\&D embodied in imports of intermediate products is examined by including $I M P E M B$. If there were any positive effect on productivity growth from R\&D embodied in imports, we would expect a positive coefficient for IMPEMB. The coefficient for IMPEMB is positive in both regression 12 and in regression 14 but the coefficients are not statistically significant. Thus, we find no productivity effects from R\&D embodied in imports of intermediate products.

DFIRD is constructed to measure the R\&D transferred through DFI. We would expect a positive coefficient for DFIRD if R\&D transferred by affiliates of foreign MNCs affects productivity growth positively. The coefficient in regression 13 has a positive and statistically significant sign. Moreover, the coefficient remains stable when the additional variables in regression 14 are included. The effect of DFI on productivity growth was found in $R \& D$

\footnotetext{
${ }^{28}$ We use Domestic industry $R \& D$ expenditures as a control variable instead of Industry $R \& D$ expenditures, as we otherwise would double-count foreign industry R\&D expenditures which are included in DFIRD.
} 
intensive industries and only in Germany, Italy and the U.K. ${ }^{29}$ The results in Table 6 are quite robust to the inclusion of different sets of dummy variables, with the exception of sector dummies which makes the coefficient for DFI statistically insignificant in regressions 13 and 14.

Table 6 - The effect on productivity growth from embodied $R \& D$ and DFI

\begin{tabular}{|l|l|l|l|l|}
\hline & Regression 11 & Regression 12 & Regression 13 & Regression 14 \\
\hline Constant & 0.002 & -0.002 & -0.003 & -0.000 \\
Business cycle & $(0.66)$ & $(0.62)$ & $(1.15)$ & $(0.09)$ \\
Domestic industry & 0.677 & 0.672 & 0.677 & 0.686 \\
R\&D expenditures & $(7.60)^{* * *}$ & $(7.50)$ & $(7.53)^{* * *}$ & $(7.75)^{* * *}$ \\
DOMEMB & $(2.07)^{* *}$ & 0.033 & 0.026 & 0.030 \\
IMPEMB & -0.564 & $(2.16)^{* *}$ & $(1.77)^{*}$ & $(1.93)^{*}$ \\
DFIRD & $--.57)$ & - & -- & -0.527 \\
Number of & -- & 0.788 & -- & $(1.43)$ \\
observations & -- & $(0.45)$ & & 1.094 \\
$\overline{\mathrm{R}^{2}}$ & & -- & 0.0007 & $(0.62)$ \\
\hline
\end{tabular}

Note: $* * *$ Coefficient significantly different from zero at the $1 \%$ level. $* *$ Coefficient significantly different from zero at the $5 \%$ level. * Coefficient significantly different from zero at the $10 \%$ level. -- Not estimated. Figures in parenthesis are t-statistics for coefficients, based on White's (1980) estimate of the covariance matrix.

\section{Discussion}

The levels of $R \& D$ expenditures affect productivity growth positively while the growth in $R \& D$ stocks has no effect on productivity growth. The results lend empirical support to endogenous growth models based on $\mathrm{R} \& \mathrm{D}$-driven growth. Looking at the results from the endogenous growth approach, there are intra-industry spillovers which seem to be present both at the domestic level and at the international level. There are no signs of inter-industry spillovers.

Most previous studies using the traditional approach have not constructed stocks of R\&D. Instead they use the R\&D-expenditures to value-added ratio. This model specification

\footnotetext{
${ }^{29}$ The results are available from the authors on request.
} 
should, in theory, be similar to our traditional model. ${ }^{30}$ Empirically, the use of R\&Dexpenditures to value-added ratios as a proxy variable for growth in R\&D-stocks seems less evident. For instance, in the case of domestic industry R\&D, the R\&D-to-value-added ratio's correlation coefficients are 0.20 for the Growth in industry $R \& D$ stock and 0.76 for the Industry $R \& D$ expenditures. Thus, the $\mathrm{R} \& \mathrm{D}$-to-value-added ratio is more correlated with our endogenous growth measure than with the traditional measure, for which it is supposed to be a proxy variable. Two conclusions can be drawn from this result. Firstly, earlier results indicating support for the traditional approach, should be seen rather as an indication that R\&D in general may have a positive effect on productivity, which is the conclusion that Sterlacchini (1989) also comes to. The second conclusion is that the results presented in our study are not that different from the results presented in other studies. Since previous studies have used R\&D measures which are similar to our endogenous growth measures, the positive effect from own industry $R \& D$ in the endogenous growth approach is in line with these earlier studies. Contrary to many earlier studies, we can find no evidence of inter-industry spillovers. ${ }^{31}$ One explanation could be that our level of aggregation is quite high and consequently we may internalise spillovers which at a lower level of aggregation would be attributed to inter-industry spillovers. Our results also differ from the ones obtained by Coe and Helpman (1995). They constructed stocks of R\&D as we did in the traditional approach and found evidence of both national and international spillovers from R\&D. One explanation of the different results could be that Coe and Helpman examined the effect of levels of R\&D stocks on levels of productivity. Different data-samples and different levels of aggregation may be other possible explanations.

Industry-specific spillovers only seemed to affect productivity growth positively in the R\&D-intensive industries. In the case of less R\&D-intensive industries, the statistical analysis produced a "perverse" effect from R\&D-expenditures to productivity growth. Although we have no explanation for this unexpected result, it seems likely that factors other than its own $R \& D$ may be important in determining productivity growth in less $R \& D$ intensive industries.

\footnotetext{
${ }^{30}$ The estimated coefficient in this case is not the output-elasticity with respect to R\&D that we estimate if we use the stock of R\&D, but rather the return to R\&D. See e.g. Sveikauskas (1981).

${ }^{31}$ For estimations of inter-industry spillovers at an industry level see e.g. Sveikauskas (1981), Scherer (1982), Sterlacchini (1989) and Bernstein and Nadiri (1991).
} 
We do not find any productivity effects from $R \& D$ embodied in intermediate products, either from domestically produced goods or from imports. These results are in line with those from Sakurai et al (1997), who found no productivity effects from embodied R\&D within the manufacturing industries. One possible reason for the lack of evidence of embodied R\&D effects could be the use of inputs of intermediate products rather than capital goods.

Finally, industries with a large share of foreign DFI from countries conducting much R\&D have experienced relatively high productivity growth. This positive effect on productivity growth from $\mathrm{R} \& \mathrm{D}$ transferred through $\mathrm{DFI}$ is in contrast to the results presented in Lichtenberg and van Pottelsberghe de la Potterie (1996), where no productivity effects from R\&D transferred through inward DFI were found. Whether the different results are due to our different approaches or the different datasets is difficult to say. We do, however, think that any positive effects are more likely to be detected in our more disaggregated data.

\section{Concluding Remarks}

This paper has analysed different aspects on spillovers from R\&D. Firstly, we examined whether levels of $R \& D$ expenditures or growth in $R \& D$ stocks affects productivity growth. Secondly, the extent of international spillovers at industry level was examined. Finally, we examined two possible channels for spillovers from R\&D.

Our two different approaches gave different results. The levels of R\&D expenditures seem to be better at capturing the effect of $R \& D$ on productivity growth. We found no evidence that growth in $R \& D$ stocks affected productivity growth. Our results therefore support the neo-traditional rather than the traditional approach. The endogenous growth approach produced evidence of intra-industry spillovers, but no signs of inter-industry spillovers. Intra-industry spillovers seem to take place both at a domestic and an international level and the spillovers seem to be confined to $R \& D$ intensive industries. Finally, the localisation of inward DFI seems to be one channel through which R\&D results are spread.

\section{Appendix}


Observations on nominal private expenditures on R\&D come from the OECD database ANBERD (1973-1991) and from the UNESCO Statistical Yearbook (1963-1973) and have been deflated by using the manufacturing price indexes from Main Economic Indicators (OECD). Observations on R\&D for the period 1973-1991 are available for all the studied industries and countries. Individual missing observations from before 1973 have been estimated by taking the average value of the preceding and the following year. Missing observations at the beginning of the period have been estimated through extrapolation. R\&D conducted before 1963 is assumed to be fully depreciated by 1978 . The sample of observations on privately funded R\&D prior to 1973 can be found in Table A1.

Table A1- Observations on private $R \& D$ expenditures over industries, countries and time periods, for the time prior to 1973

\begin{tabular}{|c|c|c|c|c|c|c|c|}
\hline Industry & ISIC & France & Germany & Italy & Japan & U.K & U.S \\
\hline Food & 3100 & $1970-72$ & $\begin{array}{l}-64,-67,-69, \\
-71\end{array}$ & $\begin{array}{l}-63,-65, \\
1967-72\end{array}$ & $1963-72$ & $1967-72$ & $1967-72$ \\
\hline Textile & 3200 & $1970-72$ & $\begin{array}{l}-64,-67,-69, \\
-71\end{array}$ & $\begin{array}{l}-63,-65 \\
1967-72\end{array}$ & $1963-72$ & $1967-72$ & $1967-72$ \\
\hline Wood & 3300 & $1970-72$ & $\begin{array}{l}-64,-67,-69, \\
-71\end{array}$ & n.a. & n.a. & n.a. & $1967-72$ \\
\hline Paper & 3400 & $1970-72$ & $-67,-69,-71$ & $\begin{array}{l}-63,-65 \\
1967-72\end{array}$ & $1963-72$ & $1967-72$ & $1967-72$ \\
\hline Chemical & 3500 & $1970-72$ & $\begin{array}{l}-64,-67,-69, \\
-71\end{array}$ & $\begin{array}{l}-63,-65 \\
1967-72\end{array}$ & $1963-72$ & $1967-72$ & $1967-72$ \\
\hline $\begin{array}{l}\text { Non- } \\
\text { metal. }\end{array}$ & 3600 & $1970-72$ & $-67,-69,-71$ & $\begin{array}{l}-63,-65, \\
1967-72\end{array}$ & $1963-72$ & $1967-72$ & $1967-72$ \\
\hline $\begin{array}{l}\text { Basic- } \\
\text { metal }\end{array}$ & 3700 & $1970-72$ & $\begin{array}{l}-64,-67,-69, \\
-71\end{array}$ & $\begin{array}{l}-63,-65, \\
1967-72\end{array}$ & $1963-72$ & $1967-72$ & $1967-72$ \\
\hline Fabr.metal & 3800 & $1970-72$ & $-67,-69,-71$ & $\begin{array}{l}-63,-65, \\
1967-72\end{array}$ & $1963-72$ & $1967-72$ & $1967-72$ \\
\hline $\begin{array}{l}\text { Other } \\
\text { manufact. }\end{array}$ & 3900 & ---------- & ---------- & $\begin{array}{l}-63,-65,-67- \\
68,1970-72\end{array}$ & $1963-72$ & $1967-72$ & $1967-72$ \\
\hline
\end{tabular}

Note: ---------- sector not included in analysis. Source: UNESCO (Various Issues)

Table A2 shows how the four different R\&D stocks are constructed for industry $i$ in country $j$ at time $t$. The R\&D stocks were constructed assuming a $5 \%$ rate of depreciation which is in line with the depreciation rate used in most previous studies. Experimentation with different depreciation rates between 0 and $10 \%$ had no major effect on the results. 
Table A2 - Constructions of R\&D stocks

\begin{tabular}{|l|l|l|l|}
\hline $\begin{array}{l}\text { Domestic industry } R \& D \\
\text { stock }\end{array}$ & $\begin{array}{l}\text { Domestic other industry } \\
R \& D \text { stock } \\
C_{i j t}^{s}=\sum_{l=t_{0}}^{t} E_{i j k}(1-\delta)^{t-l}\end{array}$ & $\begin{array}{l}\text { Foreign industry } R \& D \\
C_{i j t}^{d}=\sum_{z=1, z \neq i}^{N} C_{z j t}^{s},\end{array}$ & $\begin{array}{l}\text { Foreign other sector } \\
R \& D \text { stock } \\
C_{i j t}^{s^{*}}=\sum_{q=1, q \neq j}^{p} C_{i q t}^{s},\end{array}$ \\
$\begin{array}{l}C_{i j t}^{d^{*}}=\sum_{q=1, q \neq j}^{P} C_{i q t}^{d}, \\
\begin{array}{l}\mathrm{R} \& \mathrm{D} \text { expenditures. } \delta \text { is } \\
\text { the rate of depreciation }\end{array}\end{array}$ & $\begin{array}{l}z=1, \ldots . \mathrm{N} \text { denotes } \\
\text { industries. }\end{array}$ & $\begin{array}{l}q=1, \ldots . \mathrm{P} \text { denotes } \\
\text { countries. }\end{array}$ & $\begin{array}{l}q=1, \ldots . \mathrm{P} \text { denotes } \\
\text { countries. }\end{array}$ \\
\hline
\end{tabular}

For industry $i$ in a certain country, $D O M E M B_{J}$ measures the amount of R\&D transfer through input goods from the domestic sector $j$. IMPEMP ${ }_{i k}$ measures the amount transferred through imports of input goods from sector $j$ in country $k$. Because of data availability, we have to assume imports from different countries to have the same industry-specific distribution. For instance, Italian imports of machinery from Germany are assumed to be distributed to the domestic Italian industries in the same way as Italian imports of machinery from the U.S. DFIRD $_{i k}$ measures the amount of $\mathrm{R} \& \mathrm{D}$ transferred through localisation of MNCs from country $k$. Data on DFI is available for either specific countries or specific industries. The variable was constructed by assuming the national outward DFI-pattern to apply for each country. For instance, to construct a measure of industry-specific DFI from Germany to Italy, we took the share of Germany's total outward stock of DFI invested in each industry and multiplied it by Germany's total DFI to Italy. ${ }^{32}$ The construction of the variables is shown in Table A3.

Table A3 - Constructions of measures on purchase of intermediate products and DFI \begin{tabular}{|l|l|l}
\hline$D O M E M B_{i}=\sum_{j=1, j \neq i}^{n} \omega^{D_{i j}} E_{j}$ & $I M P E M B_{i k}=\sum_{l=1, l \neq k}^{m} \sum_{j=1, j \neq i}^{n} b_{i j k} I M P_{l j k} E_{l j}$ & DFIRD \\
$i k$ & $=\sum_{l=1, l \neq l}^{m} \omega^{F_{i l k}} E_{i l}$
\end{tabular}

\footnotetext{
${ }^{32}$ We also constructed a variable with the share of Italy's total inward stock of DFI invested in each industry multiplied by the stock of German DFI in Italy. The two proxies were very highly correlated.
} 
$\mathrm{j}=1, . . \mathrm{n}$ are industries. $E_{j}$ is $\mathrm{R} \& \mathrm{D}$ conducted in industry j. $\omega_{i j}$ is the valued of intermediate products purchased from industry $\mathrm{j}$ as a share of gross output in industry $i$. $\mathrm{l}=1, \ldots \mathrm{m}$ are countries and $b_{i j k}$ is $\omega_{i l k}^{F}$ is country 1:s stock of DFI in industry $i$ :s value of imports from industry $i$ in country $k$ as a share of industry $\mathrm{j}$ as a share of industry $\mathrm{i}: \mathrm{s}$ country $\mathrm{k}$ : $\mathrm{s}$ gross output in industry gross output. $I M P_{l j k}$ is country k:s i. import in industry $\mathrm{j}$ from country 1.

A country specific business-cycle variable is calculated for each of the six countries:

$$
\begin{aligned}
& \text { Buisiness }_{j t}=\ln Y_{j t}-\ln Y_{j t-1} \\
& j=1 \ldots 6-\text { countries, }
\end{aligned}
$$

where $Y_{j t}$ is the index of total manufacturing production in country $j$ at time $t$. The measure for business cycles has been estimated with the use of output indexes from OECD (1990) and various issues of Main Economic Indicators (OECD).

Table A4 - Summary Statistics for the Included Variables

\begin{tabular}{|l|lll|}
\hline Variable & Mean & Standard Deviation & No. of Observations \\
\hline TFP growth & 0.013 & 0.058 & 621 \\
Growth in domestic industry R\&D stock & 0.052 & 0.039 & 621 \\
Growth in foreign industry R\&D stock & 0.055 & 0.016 & 621 \\
Growth in domestic other R\&D stocks & 0.067 & 0.018 & 621 \\
Growth in foreign other R\&D stocks & 0.061 & 0.007 & 621 \\
Domestic industry R\&D expenditures & 0.027 & 0.088 & 621 \\
Foreign industry R\&D expenditures & 0.128 & 0.267 & 621 \\
Domestic other industry R\&D expenditures & 0.208 & 0.243 & 621 \\
Foreign other industry R\&D expenditures & 0.948 & 0.391 & 621 \\
Business cycle & 0.021 & 0.032 & 621 \\
DOMEMB & 0.006 & 0.009 & 608 \\
IMPEMB & 0.001 & 0.001 & 608 \\
DFIRD & 1.973 & 5.614 & 608 \\
\hline
\end{tabular}




\section{References}

Behrman, J., and H. Wallender (1976). Transfer of Manufacturing Technology within Multinational Enterprises. Cambridge: Mass.; Ballinger.

Bernstein, J., and P. Mohnen (1994). International R\&D Spillovers Between U.S. and Japanese R\&D Intensive Sectors. NBER Working Paper No. 4682.

Bernstein, J., and I. Nadiri (1991). Product Demand, Cost of Production, Spillovers, and the Social Rate of Return to R\&D. NBER Working Paper No. 3625.

Blomström, M., and A. Kokko (1997). Multinational Corporations and Spillovers. Forthcoming, Journal of Economic Surveys.

Branch, B. (1974). Research and Development Activity and Profitability: A Distributed Lag Analysis. Journal of Political Economy 82: 999-1011.

Coe, D., and E. Helpman (1995). International R\&D Spillovers. European Economic Review 39: 859-887.

Davidson, W.H., and D.G. McFetridge (1985). Key Characteristics in the Choice of International Technology Transfer. Journal of International Business Studies 15: 5-21.

Englander, A.S., and Evenson, R., and Hanzaki, M. (1988). R\&D, Innovation and the Total Factor Productivity Slowdown. OECD Economic Studies No.11.

Fors, G. (1997). Utilization of R\&D Results in the Home and Foreign Plants of Multinationals. The Journal of Industrial Economics 45: 341-358.

Globerman, S. (1997). Decentralization of Research and Development by Multinational Companies: Determinants and Future Prospects. In J. Fagerberg and Hansson, P., and Lundberg L., and Melchior, A., (eds.), Technology and International Trade. Aldershot; Edward Elgar.

Griliches, Z. (1979). Issues in Assessing the Contribution of Research and Development to Productivity Growth. The Bell Journal of Economics 10: 92-116.

Griliches, Z. (1980). R\&D and the Productivity Slowdown. American Economic Review 70: 343-348.

Griliches, Z. (1992). The Search for R\&D Spillovers. Scandinavian Journal of Economics 94: 29-47.

Grossman, G., and E. Helpman (1991). Innovation and Growth in the Global Economy. Cambridge: MIT Press.

Hulten, C. (1978). Growth Accounting with Intermediate Inputs, Review of Economic Studies 45: 511-518. 
Jones, C. (1995:a). R\&D Based Models of Economic Growth. Journal of Political Economy 103(4): 759-784.

Jones, C. (1995:b). Time Series Tests of Endogenous Growth Models. Quarterly Journal of Economics 110(2): 495-525.

Lichtenberg, F., and B. van Pottelsberghe de la Potterie (1996). International R\&D Spillovers: A Re-Examination. NBER Working Paper No. 5668.

Mansfield, E. and A. Romeo (1980). Technology Transfer to Overseas Subsidiaries by U.S.based Firms. Quarterly Journal of Economics 95: 737-750.

McFetridge, B.G. (1987). The Timing, Mode and Terms of Technology Transfer: Some Recent Findings. in A.E. Safarian and G.Y. Bertin, (eds.), Multinationals, Governments and International Technology Transfer. London: Croom Helm.

Meyer-zu-Schlochtern, F.J.M. (1988). An International Sectoral Data Base for Thirteen OECD Countries. Working Paper No 57, OECD Econometric Unit, Paris.

Nadiri, I., and S. Kim (1996). International R\&D Spillovers, Trade and Productivity in Major OECD Countries. NBER Working Paper No. 5801.

Ravenscraft, D., and F. M. Scherer (1982). The Lag Structure of Returns to Research and Development. Applied Economics 14: 603-620.

Romer, P. (1990). Endogenous Technological Change. Journal of Political Economy 98: 71102.

Sakurai, N., and Papaconstantinou, G., and Ioannidis, E. (1997). Impact of R\&D and Technology Diffusion on Productivity Growth: Empirical Evidence for 10 OECD Countries. Economic Systems Research 9: 81-109.

Schankerman, M. (1981). The Effects of Double-Counting and Expensing on the Measured Returns to R\&D. Review of Economics and Statistics 63: 454-458.

Scherer, F.M. (1982). Inter Industry Technology Flows and Productivity Growth. Review of Economics and Statistics 64: 627-634.

Shell, K. (1966). Toward a Theory of Inventive Activity and Capital Accumulation. American Economic Review 56: 155-173.

Sterlacchini, A. (1989). R\&D, Innovations, and total factor productivity growth in British Manufacturing. Applied Economics 21: 1549-1562.

Sveikauskas, L. (1981). Technology inputs and multifactor productivity growth. Review of Economic and Statistics 63: 275-282. 
